\title{
EFFECTS OF METHYLDOPA ON VEGF LEVELS AS PROANGIOGENIC FACTOR IN SEVERE PRE-ECLAMPSIA AT HAJI HOSPITAL, SURABAYA
}

\author{
Dina Ratna Juwita ${ }^{1,2}$, Yulistiani ${ }^{3}$, Eddy Zarkaty $\mathbf{M}^{4}$ \\ ${ }^{1}$ Master Program of Clinical Pharmacy, Faculty of Pharmacy, Universitas Airlangga, ${ }^{2}$ Faculty of Pharmacy, University \\ of Muhammadiyah, Purwokerto, ${ }^{3}$ Department of Clinical Pharmacy, Faculty of Pharmacy, Universitas Airlangga, \\ ${ }^{4}$ Department of Obstetrics and Gynecology, Haji Hospital, Surabaya
}

\begin{abstract}
ABSTRAK
Metildopa adalah obat pilihan utama untuk hipertensi pada kehamilan yang bekerja pada reseptor a2-adrenergik. Selain di sistem saraf pusat, reseptor a2-adrenergik juga banyak ditemukan di sel trofoblas plasenta. Metildopa menghambat pembentukan adenylyl cyclase yang berakibat pada penurunan produksi VEGF. Vascular Endothelial Growth Factor (VEGF) merupakan faktor proangiogenik dan mitogenik yang kuat untuk sel endotel dan berperan penting sebagai vasodilator. VEGF diproduksi oleh plasenta yang akan menurun karena adanya hipoksia plasenta. Tujuan penelitian ini adalah untuk menganalisis pengaruh metildopa terhadap perubahan kadar VEGF sebagai faktor proangiogenik pada pasien preeklampsia berat yang dirawat di Ruang Rawat Inap Kandungan dan Kebidanan RSU Haji Surabaya. Jenis penelitian ini adalah prospektif observasional pada periode Agustus-Oktober 2016. Data diambil sebelum dan 48 jam sesudah terapi metildopa. Penelitian ini telah mendapatkan persetujuan kelaikan etik oleh Panitia Etik Penelitian Kesehatan RSU Haji Surabaya. Terdapat 19 pasien PEB yang memenuhi kriteria inklusi. Kadar VEGF pada pasien sebelum terapi metildopa $250 \mathrm{mg}$ adalah 1178,37 \pm 1208,47 (rentang: 281,97-3567,28) pg/mL, sedangkan sesudah terapi adalah 1055,17 $\pm 1172,78$ (rentang: 129,79-4272,66) pg/mL. Kadar VEGF pada pasien sebelum terapi metildopa $500 \mathrm{mg}$ adalah 1194,29 \pm 1254,68 (rentang: 175,68-3432,01) pg/mL, sedangkan sesudah terapi adalah 510,66 $\pm 379,61$ (rentang: 214,34-1236,16) $\mathrm{pg} / \mathrm{mL}$. Berdasarkan hasil penelitian ini disimpulkan bahwa pemberian metildopa menurunkan kadar VEGF pada pasien preeklampsia berat, dengan penurunan sebesar 10\% pada pemberian dosis $250 \mathrm{mg}$ dan $57 \%$ pada pemberian dosis $500 \mathrm{mg}$. (FMI 2017;53:267-271)
\end{abstract}

Kata kunci: Metildopa; pre-eklampsia berat; VEGF

\begin{abstract}
Methyldopa is the main antihypertensive drug widely used in pregnant women with hypertensive disorder. It lowers blood pressure in pre-eclampsia by affecting a2-adrenoreceptors in central nervous system. However, it also decreases the production of proangiogenic factors that involved in the pathophysiology of hypertension in pre-eclampsia. Vascular Endothelial Growth Factor (VEGF) is one of proangiogenic and mitogenic factor that important for vasodilatation. VEGF is produced by the placenta and affected after treatment with methyldopa. The aim of this study was to analyze the effects of methyldopa on VEGF maternal circulating level as a proangiogenic factor in severe pre-eclampsia patients who were hospitalized at Obstetrics and Gynecology Department, Haji Hospital, Surabaya. This study was performed by cohort prospective observational method on August to October 2016.The data was assessed at before and 48 hours after methyldopa therapy. The study was approved by the ethical committee of Haji Hospital, Surabaya. There were 19 patients with severe pre-eclampsia who met inclusive criteria. The results showed that levels of VEGF before and 48 hours after $250 \mathrm{mg}$ methyldopa therapy were $1178.37(281.97-3567.28) \mathrm{pg} / \mathrm{mL}$ and 1055.17 (129.79-4272.66) pg/mL, respectively. VEGF levels in severe pre-eclampsia patients were 1194.29 (175.68-3432.01) pg/mL at before treatment and 510.66 (214.34-1236.16) pg/mL after treatment with methyldopa $500 \mathrm{mg}$ therapy. In conclusion, methyldopa could decrease VEGF level on severe pre-eclampsia patients, with a decrease of $10 \%$ at the dose of $250 \mathrm{mg}$ and $57 \%$ at the dose of 500 $\mathrm{mg}$. (FMI 2017;53:267271)
\end{abstract}

Keywords: Methyldopa; severe pre-eclampsia; VEGF

Correspondence: Dina Ratna Juwita, Department of Pharmacology and Clinical Pharmacy, Faculty of Pharmacy, University of Muhammadiyah, Purwokerto, Central Java. Phone: 085220165569. Email: dinaratnajuwita@gmail.com

\section{INTRODUCTION}

Severe pre-eclampsia is a condition in pregnancy which is characterized by systolic blood pressure $=160$ $\mathrm{mmHg}$, diastolic blood pressure $=110 \mathrm{mmHg}$, and proteinuria more than $5 \mathrm{~g} / 24$ hours or $4+$ on qualitative me- asure and the presence of organ failure after 20 weeks gestation (Angsar 2010, Arulkumaran \& Lightstone 2013). Severe pre-eclampsia and pre-eclampsia cause $10-15 \%$ mother mortality worldwide and $25 \%$ in Indonesia (Duley 2009, RI 2012). Maternal complications of women with pre-eclampsia include disseminated intra- 
vascular coagulopathy, acute renal failure, hepatocellular injury, liver rupture, intracerebral hemorrhage, cardiorespiratory arrest, aspiration pneu-monitis, acute pulmonary edema, and postpartum hemorrhage (Norwitz et al 2002).

Several physiology changes cause mortality and morbidity on pre-eclampsia, in which one of them is failed or incomplete trophoblast invasion. This condition leads to constriction of spiral arteries and also placental ischemia (McPhee \& Ganong 2006). Increased synthesis of soluble FMS-like tyrosine kinase-1 (sFlt-1),TNF- $\alpha$ and IL-6, angiotensin II type 1 receptor autoantibodies (AT1 -AA) and thromboxane, and decreased the level of vascular endothelial growth factor (VEGF) and placental growth factor (PIGF) are the results of placental ischemia. Further changes in these factors lead to endothelial dysfunction and then resulting in decreased nitric oxide (NO) bioavailability and increased reactive oxygen species (ROS) and endothelin-1, which in turn, results in altered renal function, increased total peripheral resistance and hypertension (Gilbert et al 2008).

The imbalance of proangiogenic and antiangiogenic factors appears 4-5 weeks before clinical manifestation of pre-eclampsia (Levine et al 2004). VEGF is a strong proangiogenic and mitogenic factor for the endothelial cell which acts as a vasodilator, produced by the placenta and will increase because of hypoxia. VEGF binds with high affinity to sFlt-1 on pre-eclampsia, resulting in decreased free VEGF level in circulation (Lee et al 2007). Methyldopa is the first choice for hypertension on pregnancy. It affects a2-adrenergic receptor by direct vasodilatation on central nervous system and decreases the production of proangiogenic protein (Khalil et al 2008). The stimulation of a2-adrenoreceptor will block adenylyl cyclase that participates in the regulation of VEGF mRNA expression (Zhang et al 2011).

A study of effect of methyldopa on angiogenic levels in pregnancies with hypertensive disorders by Khalil et al (2008) stated that VEGF level on patients who received methyldopa was lower than those who did not receive methyldopa therapy. In Indonesia, no previous data are available regarding methyldopa effect on the angiogenic level in women with pre-eclampsia. Therefore, we need research on the effect of methyldopa on VEGF level on women with pre-eclampsia. The results of this study are expected to be used as a means to develop guidelines on the use of methyldopa at Haji Hospital, Surabaya.

\section{MATERIALS AND METHODS}

\section{Sample}

A cross-sectional, observational prospective study was conducted at Haji Hospital, Surabaya from August to October 2016. Patients were selected based on inclusion and exclusion criteria. The inclusion criteria were as follows: (1) patients with severe pre-eclampsia who received methyldopa at least 48 hours; (2) single or multiple pregnancies; and (3) willing to participate in the study by signing the informed consent. The patients received oral methyldopa therapy $250 \mathrm{mg}$ or $500 \mathrm{mg}$ three times a day at least 48 hours. Patients which were diagnosed with pre-eclampsia postpartum and received methyldopa from the beginning of pregnancy or contraindicated with methyldopa were excluded from this study. This study was approved by ethical committee of Haji Hospital, Surabaya.

Plasma samples were obtained from venous blood sample before and after 48 hours methyldopa therapy in $\mathrm{BD}$ vacutainer tube with EDTA. The samples were centrifuged at $3000 \mathrm{rpm}$ for ten minutes. The plasma was separated and frozen at $-80^{\circ} \mathrm{C}$ for subsequent analysis. Using commercially available kit for measurement of human VEGF (Bioassay Technology Laboratory, Shanghai, China), enzyme linked immunosorbent assay (ELISA) were conducted according to the manufacturer's protocol. The minimum detectable level for plasma VEGF was $20 \mathrm{pg} / \mathrm{ml}$.

\section{Data analysis and statistics}

Descriptive analysis was performed to determine the patient demographic data. Shapiro-Wilk test was used to assess the normality of data. Wilcoxon test was used to compare VEGF levels before and after methyldopa therapy because data were abnormally distributed. MannWhitney test was used to compare VEGF levels between $250 \mathrm{mg}$ dose group and $500 \mathrm{mg}$ dose group. Data were analyzed using SPSS® (SPSS version 20, 2011, SPSS Inc., Chicago, Illinois, USA). Results were considered statistically significant if $\mathrm{p}<0.05$.

\section{RESULTS}

The results showed that out of 22 patients, there were 19 patients who met the inclusion criteria, whereas 3 patients were excluded because they were diagnosed with severe pre-eclampsia postpartum, and 1 of them received one dose of methyldopa. Baseline characteristics of patients is mentioned in Table 1 , meanwhile VEGF levels before and after administration of methyldopa are shown in Table 2.

Mean of VEGF levels before and after administration in methyldopa $250 \mathrm{mg}$ group were $1178.37 \pm 1208.47$ (281.97-3567.28) $\mathrm{pg} / \mathrm{ml}$ and $1055.17 \pm 1172.78$ (129.79 
-4272.66) $\mathrm{pg} / \mathrm{ml}$, respectively. Meanwhile, in methyldopa 500 mg group, VEGF levels before and after administration were $1194.29 \pm 1254.68(175.68-3432.01)$ $\mathrm{pg} / \mathrm{ml}$ and $510.66 \pm 379.61(214.34-1236.16) \mathrm{pg} / \mathrm{ml}$. In statistical test to parameters of VEGF levels before and after administration of methyldopa, both in abnormal distribution $(\mathrm{p}<0.05)$. Because of abnormal data distribution, we used Wilcoxon test. Based on statistical analysis results, VEGF levels before and after administration of methyldopa $250 \mathrm{mg}$ not significantly different ( $\mathrm{p}=0.422$ ), but VEGF level after administration of methyldopa $500 \mathrm{mg}$ administration significantly different than before administration $(\mathrm{p}=0.045)$. Figure 1 shows VEGF levels in both doses.

Table 1. Baseline characteristics of the patients

\begin{tabular}{|c|c|c|}
\hline Characteristics & $\begin{array}{c}\text { Patients } \\
(\mathrm{N}=19)\end{array}$ & $\begin{array}{c}\text { Percentage } \\
(\%)\end{array}$ \\
\hline \multicolumn{3}{|l|}{ Age (year) } \\
\hline $20-24$ & 2 & 11 \\
\hline $25-29$ & 5 & 26 \\
\hline $30-34$ & 5 & 26 \\
\hline $35-39$ & 4 & 21 \\
\hline$\geq 40$ & 3 & 16 \\
\hline \multicolumn{3}{|l|}{ Gravidity } \\
\hline Primigravida & 18 & 95 \\
\hline Multigravida & 1 & 5 \\
\hline \multicolumn{3}{|l|}{ Gestational Age (weeks) } \\
\hline $36-<37$ & 9 & 47 \\
\hline $37-<38$ & 6 & 32 \\
\hline $38-<39$ & 1 & 5 \\
\hline $39-\leq 40$ & 3 & 16 \\
\hline \multicolumn{3}{|c|}{ Sistolic Blood Pressure (mmHg) } \\
\hline$<160$ & 3 & 16 \\
\hline $160-<170$ & 5 & 26 \\
\hline $170-<180$ & 4 & 21 \\
\hline $180-<190$ & 4 & 21 \\
\hline $190-<200$ & 4 & 5 \\
\hline$\geq 200$ & 2 & 11 \\
\hline \multicolumn{3}{|c|}{ Diastolic Blood Pressure (mmHg) } \\
\hline$<110$ & 11 & 58 \\
\hline $110-<120$ & 3 & 16 \\
\hline$\geq 120$ & 5 & 26 \\
\hline \multicolumn{3}{|l|}{ Proteinuria } \\
\hline Negative & 4 & 21 \\
\hline$+1(25 \mathrm{mg} / \mathrm{dL})$ & 2 & 11 \\
\hline$+2(75 \mathrm{mg} / \mathrm{dL})$ & 5 & 26 \\
\hline$+3(150 \mathrm{mg} / \mathrm{dL})$ & 1 & 5 \\
\hline$+4(500 \mathrm{mg} / \mathrm{dL})$ & 7 & 37 \\
\hline \multicolumn{3}{|l|}{ Edema } \\
\hline Positive & 12 & 63 \\
\hline Negative & 7 & 37 \\
\hline \multicolumn{3}{|l|}{ Methyldopa Dose } \\
\hline $250 \mathrm{mg}$ & 13 & 68 \\
\hline $500 \mathrm{mg}$ & 6 & 32 \\
\hline \multicolumn{3}{|l|}{ Contraceptive History } \\
\hline None & 12 & 63 \\
\hline Intramuscular & 5 & 26 \\
\hline Oral & 2 & 11 \\
\hline
\end{tabular}

Table 2. VEGF levels before and after administration

\begin{tabular}{|c|c|c|c|}
\hline \multirow{2}{*}{$\begin{array}{c}\text { Patients' } \\
\text { Initials }\end{array}$} & \multicolumn{2}{|c|}{ VEGF Level (pg/ml) } & \multirow{2}{*}{$\Delta$} \\
\hline & Before & After & \\
\hline \multicolumn{4}{|c|}{ Methyldopa $250 \mathrm{mg}$} \\
\hline MS & 448.66 & 129.79 & -318.87 \\
\hline HL & 588.76 & 583.93 & -4.83 \\
\hline SZ & 1030.83 & 699.88 & -330.95 \\
\hline MJ & 3567.28 & 4272.66 & 705.38 \\
\hline WD & 2555.12 & 2023.67 & -531.45 \\
\hline TS & 487.31 & 576.69 & 89.38 \\
\hline $\mathrm{AH}$ & 434.16 & 231.24 & -202.92 \\
\hline SMP & 344.78 & 371.35 & 26.57 \\
\hline EJ & 709.55 & 878.64 & 169.09 \\
\hline SMD & 545.28 & 571.85 & 26.57 \\
\hline SN & 281.97 & 153.94 & -128.03 \\
\hline $\mathrm{KN}$ & 3564.87 & 2296.64 & -1268.23 \\
\hline WY & 760.28 & 926.96 & 166.68 \\
\hline \multicolumn{4}{|c|}{ Methyldopa $500 \mathrm{mg}$} \\
\hline EM & 467.98 & 294.05 & -173.93 \\
\hline KS & 767.52 & 547.70 & -219.82 \\
\hline $\mathrm{EF}$ & 175.68 & 214.34 & 38.66 \\
\hline SK & 1907.72 & 1236.16 & -671.56 \\
\hline SR & 3432.01 & 501.80 & -2930.21 \\
\hline IM & 414.84 & 269.90 & -144.94 \\
\hline
\end{tabular}

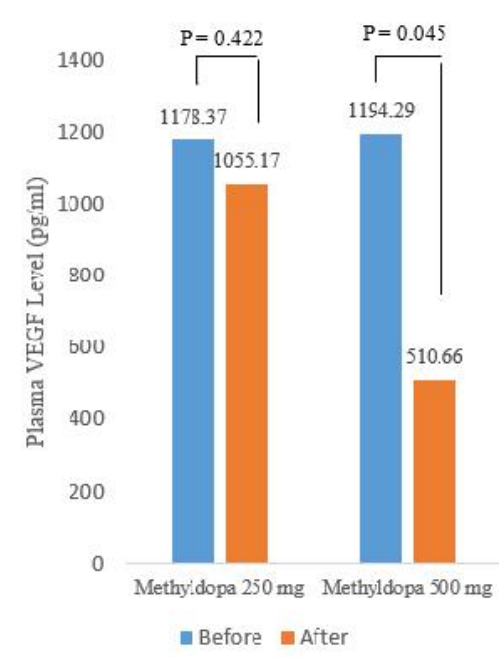

Fig. 1. VEGF levels before and after methyldopa administration.

Mann-Whitney test was used to compare the significance of methyldopa administration with different dose. The results showed that there was no significant difference between methyldopa $250 \mathrm{mg}$ and $500 \mathrm{mg}$, statistically $(\mathrm{p}=0.188)$.

\section{DISCUSSION}

In this study, patients should fulfill inclusive criteria which was receiving methyldopa therapy at least 48 hours. This is based on a study by Khalil et al (2008) 
stating that angiogenic factors would decrease significantly after 48 hours of delivery. The demo-graphic data showed severe pre-eclampsia happened mostly at productive age. Nevertheless, older maternal age (with $37 \%$ patients older than 35 years old) increases risks of pre-eclampsia. It happens because age affects the stiffness of arteries. Furthermore, alteration of vascular structure also influences elasticity of blood vessels (Hasibuan \& Aminuddin 2012).

Based on previous study, VEGF level on normal pregnancy reaches the highest level at gestational age more than 37 weeks (Bosio et al 2001), so the subjects for this study were taken when pregnancy entered the third trimester. In this study, patients who received methyldopa went through delivery within 48 hours. VEGF level will decrease rapidly after parturition because the primary source of VEGF during pregnancy is the placenta. The half-life of VEGF in circulation is very short, approximately 3 minutes (Folkman 1995). The measurement of blood pressure is commonly used to predict pre-eclampsia. Accurate prediction in high risk women with pre-eclampsia is substantial as a preventive measure, with the aim to improving maternal and neonatal outcomes. In addition to systolic and diastolic pressure, mean arterial pressure (MAP) can be used and a better predictor for pre-eclampsia (Cnossen et al 2008). Mean arterial pressure is average arterial pressure during the single cardiac cycle. Normal MAP ranges from 70 to $100 \mathrm{mmHg}$. Women who are predicted with pre-eclampsia have higher MAP at first and second trimester than normal pregnancy (Easterling et al 1990).

The results showed that 15 out of 19 patients experienced proteinuria. Proteinuria occurs on pre-eclampsia because of endothelial cells damage on glomerulus, furthermore, leads to capillary leakage (Cunningham et al 2010). From the previous studies, VEGF levels in plasma and placenta on pre-eclampsia women was higher than normotensive pregnant women (Bosio et al 2001, Khalil et al 2008). However, on pre-eclamp-sia, VEGF binded with high affinity with sFlt-1, so free VEGF level very low, even below detection level (Lam et al 2005, Madazli et al 2003, Sulistyowati et al 2014). Based on same gestational age, VEGF levels in preeclampsia patients before administration in this study was lower than VEGF levels on normal pregnancy in the previous studies. Mean plasma VEGF level decreased approximately $10 \%$ after methyldopa $250 \mathrm{mg}$ administration, although it was not statistically significant $(\mathrm{p}=0.422)$. However, after $500 \mathrm{mg}$ methyldopa therapy, mean plasma VEGF level decreased approximately $57 \%$ and it was significant $(\mathrm{p}=0.045)$. This results are consistent with a study by Khalil et al (2008) that showed lower VEGF level after administration of methyldopa compared with patients without therapy.
Methyldopa acts by stimulating $\alpha 2$-adrenoreceptor which blocks adenylyl cyclase that leads to decreased cAMP production. Furthermore, this condition will prevent angiogenic genes transcription, among others VEGF and VEGFR-1, so VEGF production will decrease (Zhang et al 2011). From 19 patients, there were 7 patients whose VEGF level after therapy was higher than before (Table 2). There are three causes that can increase VEGF levels. Adenosine accumulation, which occurs at hypoxia condition, has effect on VEGF genes induction during hypoxia. Several cytokines and growth factors also increase mRNA VEGF expression or induced VEGF protein release. Exposure of TGF- $\beta$, TGF- $\alpha$, IL- $1 \alpha$ and other factors as epidermal growth factor (EGF) and $\mathrm{PGE}_{2}$ also stimulate VEGF release. It indicates that these factors contribute to angiogenesis mechanism in inflammation. Differentiation and cell transformation also affect VEGF gene expression, such as wound healing process (Ferrara \& Davis-Smyth 1997). Based on this study, VEGF as proangiogenic fac-tor needs consideration as a biomarker associated with endothelial cell damage in pregnancy with severe preeclampsia.

\section{CONCLUSION}

Methyldopa could decrease VEGF level on severe preeclampsia patients, with a decrease of $10 \%$ at the dose of $250 \mathrm{mg}$ and $57 \%$ at the dose of $500 \mathrm{mg}$.

\section{REFERENCES}

Angsar MD (2010). Hipertensi dalam kehamilan. In S. Prawirohardjo, Ilmu Kebidanan, Jakarta, PT. Bina Pustaka Sarwono Prawirohardjo, p 530-50

Arulkumaran N, Lightstone L (2013). Severe preeclampsia and hypertensive crises. Best Practice \& Research Clinical Obstetrics and Gynecology 27, 87784

Bosio PM, Wheeler T, Anthony F, et al (2001). Maternal plasma vascular endothelial growth factor concentrations in normal and hypertensive pregnancies and their relationship to peripheral vascular resistance. American Journal of Obstetric \& Gynecology, 146-52

Cnossen JS, Vollebregt KC, de Vrieze N, et al (2008). Accuracy of mean arterial pressure and blood pressure measurements in predicting pre-eclampsia: systematic review and meta-analysis'. BMJ 336, 1117

Cunningham F, Leveno KJ, Bloom SL, et al (2010). Williams obstetric. 23th ed, New York, McGraw-Hill Education, p 707-56

Duley L (2009). The global impact of pre-eclampsia and eclampsia. Seminar of Perinatology 33, 130-7 
Easterling TR, Benedetti TJ, Schmucker BC, Millard SP (1990). Maternal hemodynamics in normal and preeclamptic pregnancies: a longitudinal study. Obstetrics \& Gynecology 76, 1061-9

Ferrara N, Davis-Smyth T (1997). The biology of vascular endothelial growth factor. Endocrine Reviews $18,4-25$

Folkman J (1995). Angiogenesis in cancer, vascular, rheumatoid, and other disease. Nature Medicine 1, 2731

Gilbert JS, Ryan MJ, LaMarca BB, Sedeek M, Murphy SR (2008). Pathophysiology of hypertension during pre-eclampsia: linking placental ischemia with endothelial dysfunction. Am.J.Physiol Heart Circ Physiol 294, 541-50

Hasibuan FS, Aminuddin M (2012). Hipertensi pada geriatri. In: Pikir BS, Aminuddin M, Subagjo A, Dharmadjati $\mathrm{BB}$, et al, Hipertensi manajemen komprehensif, Surabaya, Universitas Airlangga

Khalil A, Muttukrishna S, Harrington K, Jauniaux E (2008). Effect of antihypertensive therapy with alpha methyldopa on levels of angiogenic factor in pregnancies with hypertensive disorders. PLoS ONE 3, e2766

Lam C, Lim K, Karumanchi S (2005). Circulating angiogenic factors in the pathogenesis and prediction of pre-eclampsia. Hypertension, 1077-85

Lee ES, Oh MJ, Jung JW (2007). The levels of circulating vascular endothelial growth factor and soluble Flt-1 in pregnancies complicated by pre-eclampsia'. J Korean Me Sci 22, 94-8
Levine RJ, Maynard SE, Qian C, et al (2004). Circulating angiogenic factors and the risk of pre-eclampsia. The New England Journal of Medicine 304, 67283

Madazli R, Aydin S, Uludag S, Vildan O, Tolun N (2003). Materal plasma levels of cytokines in normal and preeclamptic pregnancies and their relationship with diastolic blood pressure and fibronectin levels. Acta Obstetricia et Gynecologica Scandinavica 82, 797-802

McPhee SJ, Ganong WF (2006). Pathophysiology of disease: an introduction to clinical medicine. 5th ed, United States, The McGraw-Hill Companies, Inc, p 295-317

Norwitz E, Hsu C, Repke J (2002). Acute complications of pre-eclampsia. Clinical Obstetric and Gynecology 45, 308-29

RI, Kementrian Kesehatan (2012). Upaya percepatan penurunan angka kematian ibu

Sulistyowati S, Roswendi A, Kartika H, Respati SH (2014). Kadar soluble human leukocyte antigen-G (sHLA-G), vascular endothelial growth factor (VEGF) dan soluble Fms-like tyrosine kinase-1 (sFLT-1) pada pre-eklampsia. Majalah Obstetri \& Gynecology 22, 126-31

Zhang ZH, Yin DZ, Wang ZC (2011). Contribution of hypoxia-inducible factor-1alpha to transcriptional regulation of vascular endothelial growth factor in bovine developing luteal cells. Animal Science Journal 82, 244-50 